\title{
PENGECETAN HATI PKK
}

\author{
NURANI \\ NIM : : 9173770410369 \\ EMAIL: Nurani21093@gmail.com
}

\section{Bentuk Kegiatan}

Pengecetan Hati PKK di

Dusun

Balangloe

Tarowang.

\section{Lokasi}

Dusun Balangloe, Desa Balangloe tarowang, kec. Tarowang

\section{Hari/Tanggal dan Waktu}

Pada hari Rabu Tanggal

21 Oktober 2020

Pukul 15:20 wita

4.Peserta yang Dilibatkan

-Peserta KKLP.

\section{Alasan Diadakannya}

Agar masyarakat tahu

Point-point Hati PKK

6.Tujuan dan Manfaat
- Tujuan,

Untuk menciptakan Ketahanan Pangan Keluarga

- Manfaat, Masyarakat bisa membaca point apa saja yang terdapat pada hati PKK

7. Produk Kegiatan (Jika Ada)

-Cat

-Tinner

-Kuas

-Pilos

\section{Deskripsi Kegiatan}

Yaitu

Melakukan

pengecetan Hati PKK. Di

Dusun Balangloe, Desa Balangloe Tarowang. Pada Hari Kamis, Tanggal 21 Oktober 2020 untuk memper Indah dan Menampakkan Warna- 
warninya agar Lebih Jelas

Terlihat.

\section{Referensi Wajib}

- HERIANTO, H., \& Amir, A. S. (2020, September 10). Pedoman Pelaksanaan Kuliah Kerja Lapangan Plus (KKLP) Mahasiswa STIE dan STKIP YAPTI Jeneponto. https://doi.org/10.31219/osf.io/7dvpk 